\title{
Credit of small and medium sized scientific and technological enterprises based on BP neural network Evaluation research
}

\author{
Liulu Zhang ${ }^{1}$, and Xiao Zuo ${ }^{2, *}$ \\ ${ }^{1}$ Doctor of economics, Professor, master supervisor of Shanghai Institute of Technology, Research \\ direction: financial science and technology;201418 Shanghai China \\ ${ }^{2} \mathrm{~A}$ graduate student, majored in management science and engineering, Shanghai Institute of \\ Technology. Research direction: innovation and development of financial science and \\ technology.201418 Shanghai China
}

\begin{abstract}
Aiming at the problem of credit evaluation of science and technology-based small and medium-sized enterprises in China, a credit evaluation system based on machine learning is proposed. A total of 17 indicators are selected from five aspects of solvency, profitability, operation ability, growth ability and R \& D ability. Finally, 11 representative indicators are selected. Then through BP neural network algorithm to build a credit evaluation model, training and Simulation of the credit rating of science and technology-based SMEs. The results show that the evaluation model has good generalization ability, and can effectively evaluate the credit of science and technology-based SMEs.
\end{abstract}

\section{Introduction}

With the rapid development of information technology and the arrival of the era of big data, small and medium-sized enterprises, especially technological small and medium-sized enterprises, as the micro carrier of innovation and the pillar of the real economy, play an increasingly important role, and have become an important part of China's economic system. They not only pay $50 \%$ of the national tax, but also provide labor employment rate of $80 \%$.

Compared with the relatively mature large and medium-sized enterprises, the credit risk assessment technology of small and medium-sized scientific and technological enterprises in China is still in its infancy, lacking an effective credit risk evaluation system.Although the development of foreign countries in this aspect is relatively perfect, but the foreign development system is not suitable for China's small and medium-sized enterprises, so we can only learn from them instead of copying them. This paper is based on this problem, using the method of machine learning to build a credit evaluation model suitable for China's small and medium-sized enterprises, and bring the actual data into it for calculation and training,So as to ensure the effectiveness and practicability.

\footnotetext{
*Corresponding author: 1923418773@qq.com
} 


\section{Literature review}

Construction of credit evaluation index system, credit default influencing factors, credit risk assessment, credit evaluation methods and so on. Jones (2015) classified enterprise credit rating indicators based on the nonlinear discrimination of neural network and support vector machine ${ }^{[2]}$. Anonymous (2009) believes that it is not practical and scientific to directly measure small and medium-sized technology enterprises by the standard of large enterprises when studying the credit status of enterprises, which is not conducive to the healthy development of small and medium-sized technology-based enterprises. ${ }^{[4]}$

In terms of index construction, fan bainai and Zhu Wenbin (2003) constructed 28 evaluation index systems from six aspects of solvency, operation ability, profit making ability, management ability and innovation ability; ${ }^{[5]}$ Wang Shuai (2014) and others designed an index system including industry status, upstream and downstream status, product status, management level, financial status and credit status. ${ }^{[6]}$ Ludovic (2020) used the combination weighting method and linear weighting method to construct the credit evaluation index system of small and medium-sized enterprisesBank credit risk assessment $^{[1]}$.

\section{The present situation of credit evaluation of small and medium sized enterprises of science and technology}

In recent years, China's high-tech industry has developed rapidly, and the profits of high-tech manufacturing industry and strategic emerging industries have maintained growth. However, small and medium-sized enterprises are still facing difficulties and problems in financing. The real reason is that the information of small and medium-sized scientific and technological enterprises and financial institutions is not equal. In view of this problem, we can effectively eliminate the information imbalance between them by credit rating enterprises. This practice can also solve the imbalance between enterprises and financial institutions, which is conducive to further development of enterprises. From the perspective of the average annual wage of employees in different industries of Urban Non private units in 2019, information transmission, software and information technology service industry, scientific research and technical service industry have absolute advantages in promoting national economic development.This is also the reason for the sample data to select these four industries.

\section{Overview of neural network and analysis of its advantages and disadvantages}

Artificial neural network (ANN)Neural network (ANN) is referred to as neural network (ANN). The principle of the neural network is proposed according to biology. It is mainly through the study of human brain to understand its internal structure. Then the network topology theory is used to simulate the structure of human brain.

\subsection{Overview of BP neural network}

BP neural network is a kind of multilayer feed forward neural network based on back propagation algorithm. BP algorithm is the most successful neural network learning algorithm so far.This algorithm is also the most commonly used training algorithm in related research.BP algorithm is not only limited to multilayer feed forward neural network, but also can be used in other networks. Figure 2 is a relatively simple BP neural network. 
We can make simple assumptions on some of the values. For example, suppose that the hidden unit is 5 , the weight value from input layer to hidden layer is $\mathrm{w}$, the bias term is B1, the activation function is G1, the weight value from hidden layer to output layer is $\mathrm{V}$, the offset term is B2, and the activation function is $\mathrm{G} 2$ :

$$
\hat{Y}=g_{2}\left(V^{T} g_{1}\left(W^{T} X+b_{1}\right)+b_{2}\right)
$$

\subsection{Advantages of BP neural network in solving classification problems}

1.Nonlinear mapping ability: in essence, BP is a process from input to output, which can be interpreted as the mapping mentioned in mathematics, and through mathematics.

2.Self learning and adaptive ability: through relevant training, we found that BP can extract and summarize the rules between the data by self-learning, and memorize them, and calculate them into the weight. This fully reflects the learning and adaptability of BP.

3.Generalization ability: the generalization mentioned here is not the generalization in the field of psychology, but refers to that the pattern classifier needs to consider both the classification of objects and whether the website can classify new patterns.

4.Fault tolerance: BP has a unique ability, that is, all parts work together and are independent of each other. As long as it can work normally without comprehensive damage, it can be said that its fault tolerance ability is very strong.

\section{Empirical research}

\subsection{Establishment of credit risk evaluation system, sample description and evaluation index screening of small and medium-sized technological enterprises}

\subsubsection{Establishing credit risk evaluation system for small and medium sized enterprises}

This paper makes a comprehensive analysis on the development status and existing problems of the credit rating system for small and medium-sized technology-based enterprises. Combined with the characteristics of small and medium-sized technology-based enterprises, the index of R \& D capacity is added to the traditional index system, as shown in Table 1.And then put forward relevant optimization suggestions to make the credit rating system of small and medium-sized technology-based enterprises more perfect and better adapt to the opportunities and challenges brought by the Internet environment.

\subsubsection{Sample description}

According to the "Interim Provisions on standards for small and medium-sized enterprises" issued and approved by the Ministry of Finance and the National Development Planning Commission, as well as the definition of small and medium-sized technology-based enterprises in the guidance of key projects of Technology Innovation Fund for small and medium-sized enterprises in 2016 prepared by the Ministry of Science and technology, this paper divides them into two categories: information transmission, software and information technology service industry, scientific research and technology service industry. Among the 
high-tech industries, 600 small and medium-sized technology-based enterprises are selected as samples.

Table 1. Credit risk evaluation index system of scientific and technological SMEs.

\begin{tabular}{|c|c|c|c|}
\hline $\begin{array}{l}\text { Primary } \\
\text { indicators }\end{array}$ & $\begin{array}{l}\text { Secondary } \\
\text { indicators }\end{array}$ & grade & Calculation formula \\
\hline \multirow[t]{3}{*}{ Solvency } & Current ratio & $\mathrm{X} 1$ & $\begin{array}{c}\text { Current ratio }=\text { total current assets } / \text { total current } \\
\text { liabilities }\end{array}$ \\
\hline & Quick ratio & $\mathrm{X} 2$ & $\begin{aligned} \text { Quick ratio }= & (\text { total current assets net inventory }) / \\
& \text { total current liabilities }\end{aligned}$ \\
\hline & Equity ratio & $\mathrm{X} 3$ & Equity ratio $=$ Total Liabilities $/$ total owner's equity \\
\hline \multirow[t]{4}{*}{$\begin{array}{l}\text { Profitabili } \\
\text { ty }\end{array}$} & $\begin{array}{l}\text { Basic earnings per } \\
\text { share }\end{array}$ & $\mathrm{X} 4$ & $\begin{array}{c}\text { Basic earnings per share }=\text { current net profit } \\
\text { attributable to ordinary shareholders / weighted } \\
\text { average number of common shares issued in the } \\
\text { current period }\end{array}$ \\
\hline & $\begin{array}{l}\text { net asset value per } \\
\text { share }\end{array}$ & $\mathrm{X} 5$ & $\begin{array}{l}\text { Net assets per share }=\text { shareholders' equity at the end } \\
\text { of the year / total number of common shares at the } \\
\text { end of the year }\end{array}$ \\
\hline & Return on net assets & $\mathrm{X} 6$ & $\begin{array}{c}\text { Return on net assets }=\text { net profit / average net assets } \times \\
100 \%\end{array}$ \\
\hline & $\begin{array}{l}\text { Gross profit margin } \\
\text { of sales }\end{array}$ & $\mathrm{X} 7$ & $\begin{array}{c}\text { Gross profit rate of sales }=(\text { sales revenue }- \text { sales cost }) \\
\qquad / \text { sales revenue } \times 100 \%\end{array}$ \\
\hline \multirow{3}{*}{$\begin{array}{l}\text { Operation } \\
\text { al } \\
\text { capability }\end{array}$} & Business cycle & $\mathrm{X} 8$ & $\begin{array}{c}\text { Business cycle }=\text { inventory turnover days }+ \text { accounts } \\
\text { receivable turnover days }\end{array}$ \\
\hline & $\begin{array}{c}\text { Inventory turnover } \\
\text { days }\end{array}$ & $\mathrm{X} 9$ & $\begin{array}{c}\text { Inventory turnover days }=360 \text { / ( cost of sales / } \\
\text { average inventory amount) }\end{array}$ \\
\hline & $\begin{array}{l}\text { Days sales } \\
\text { outstanding }\end{array}$ & $\mathrm{X} 10$ & $\begin{array}{l}\text { Accounts receivable turnover days }=\text { average } \\
\text { accounts receivable } \times 360 \text { days } / \text { sales revenue }\end{array}$ \\
\hline \multirow{4}{*}{$\begin{array}{l}\text { Ability to } \\
\text { grow }\end{array}$} & $\begin{array}{l}\text { Year on year growth } \\
\text { rate of earnings per } \\
\text { share }\end{array}$ & $\mathrm{X} 11$ & $\begin{array}{c}\text { Year on year growth rate of earnings per share }= \\
\text { (earnings per share of the current period - earnings } \\
\text { per share of the previous period) } / \text { (earnings per share } \\
\text { of the previous period) } \times 100 \%\end{array}$ \\
\hline & $\begin{array}{l}\text { Year on year growth } \\
\text { rate of operating } \\
\text { revenue }\end{array}$ & $\mathrm{X} 12$ & $\begin{array}{l}\text { Year on year growth rate of operating revenue }= \\
\text { (current operating revenue }- \text { last period operating } \\
\text { revenue) / last period operating revenue } \times 100 \%\end{array}$ \\
\hline & $\begin{array}{l}\text { Year on year growth } \\
\text { rate of net profit }\end{array}$ & $\mathrm{X} 13$ & $\begin{array}{c}\text { Year on year growth rate of net profit }=(\text { current net } \\
\text { profit - last period net profit }) / \text { last period net profit } \times \\
100 \%\end{array}$ \\
\hline & $\begin{array}{l}\text { Return on net assets } \\
\text { increased year on } \\
\text { year }\end{array}$ & $\mathrm{X} 14$ & $\begin{array}{c}\text { Year on year growth rate of return on assets }=(\text { return } \\
\text { on net assets in the current period - return on net } \\
\text { assets in the previous period }) /(\text { return on net assets in } \\
\text { the long term }) \times 100 \%\end{array}$ \\
\hline \multirow[t]{3}{*}{$\begin{array}{l}\text { R \& D } \\
\text { capability }\end{array}$} & $\begin{array}{l}\text { Total R \& D } \\
\text { expenditure }\end{array}$ & $\mathrm{X} 15$ & $\begin{array}{l}\text { Total R \& D expenditure (intangible assets are the } \\
\text { core resources of technology-based enterprises, } \\
\text { which is an important indicator to measure the } \\
\text { competitiveness of total R \& D expenditure of core } \\
\text { competitiveness of technology-based enterprises) }\end{array}$ \\
\hline & $\begin{array}{l}\text { Proportion of R \& } \\
\text { D expenditure to net } \\
\text { assets }\end{array}$ & $\mathrm{X} 16$ & $\begin{array}{c}\text { Ratio of R \& D expenditure to net assets }=\text { R \& D } \\
\text { expenditure / net assets }\end{array}$ \\
\hline & $\begin{array}{l}\text { Proportion of R \& } \\
\mathrm{D} \text { expenditure to } \\
\text { operating revenue }\end{array}$ & $\mathrm{X} 17$ & $\begin{array}{c}\text { Ratio of R \& D expenditure to operating revenue }=\mathrm{R} \\
\& \mathrm{D} \text { expenditure / operating income }\end{array}$ \\
\hline
\end{tabular}




\subsubsection{Selection of evaluation indexes}

After preliminary screening, this paper classifies the indicators of credit evaluation. There are 17 indicators in total. The detailed indicators can be viewed in Table 2. However, due to the great correlation among these indicators, detailed discussion and screening are needed to select the most suitable indicators.

The first step is t-test. For some indicators with large differences in the data, we need to filter out, delete the remaining indicators, after testing, a total of six indicators are removed.

The second step is to reduce dimension by factor analysis. It is mainly on the basis of not destroying the original variables to extract the common factors, so as to improve the group correlation as much as possible, while the relationship and correlation between groups are reduced as much as possible, which is what we call reduction. On the other hand, under the same conditions, the larger the error of the selected model will increase, which may lead to the decrease of the load on the same degree of training, Neural networks can also become unstable.

Table 2. Applicability test of factor analysis

\begin{tabular}{|c|c|c|}
\hline \multicolumn{2}{|c|}{ Kaiser Meyer Olkin measure of sampling adequacy } & 0.637 \\
\hline \multirow{3}{*}{ Bartlett's sphericity test } & Approximate chi square & 691.474 \\
\cline { 2 - 3 } & DF & 55 \\
\cline { 2 - 3 } & Sig. & 0.000 \\
\hline
\end{tabular}

According to the test results in Table 3, KMO statistic $=0.367>0.5$, indicating that the overlapping degree among variables is not high. In addition, the significance level $\mathrm{P}$ is less than 0.05 , which shows that the correlation coefficient matrix is not a unit matrix. Therefore, it is necessary to reduce the dimension of sample data by factor analysis. Finally, the variables corresponding to each sample are reduced to three, that is, one enterprise corresponds to three principal component factors. According to the factor load and economic implication of the three principal components, they are named as growth ability factor, R \& D profitability factor and solvency factor.

\subsection{Evaluation process and empirical results of credit risk model based on BP neural network}

\subsubsection{Credit risk model evaluation process}

First of all, we need to conduct a detailed study on the enterprise, define the risk indicators through the understanding of the enterprise, and formulate the index system simply. Then we use t-test to eliminate the unsuitable indicators. For the remaining indicators, we can reduce the dimension of the factors. The final indicators have a certain degree of reliability and validity. At this time, we can deal with the final results input into BP, the network model will randomly group the input data, and then train and test in the group, and retain the samples. Finally, according to the existing samples, the nonlinear relationship between input and output is systematically trained. During the training, the neural network can learn autonomously and adjust the weights to establish the mapping relationship,After that, the inspection after the test can be carried out.

\subsubsection{Analysis of empirical results}

This paper uses spss22 to realize the construction and operation of BP neural network model. The input layer is composed of three factors, the output layer is credit rating, and 
two neurons. The final training results are shown in Table 4.The credit risk evaluation model classifies all training samples accurately, and the classification accuracy rate of test samples is $90.5 \%$. After calculation, the classification accuracy rate of the total samples reaches $97 \%$. It can be seen that the prediction accuracy of this model is very high, the error rate of judgment is very low, and the stability is strong.

Table 3. Training results of BP neural network model.

\begin{tabular}{|c|c|c|c|}
\hline sample & $\mathrm{N}$ & percentage & Correct percentage \\
\hline train & 450 & $68.2 \%$ & $100 \%$ \\
\hline test & 210 & $31.8 \%$ & $90.5 \%$ \\
\hline Total sample & 660 & 100 & $97 \%$ \\
\hline
\end{tabular}

\section{Conclusion}

The construction of the credit evaluation model, on the one hand, helps the scientific and technological financial institutions to screen and supervise the technology-based enterprises, reduce the transaction costs, broaden the investment channels, avoid the loan risk to the maximum extent, and effectively avoid the phenomenon of "bad money chasing good money"; on the other hand, it solves the dilemma of small and medium-sized enterprises based on intangible assets that are difficult to obtain credit support to reduce the cost of financing, promoting scientific and technological innovation, and stimulating economic growth. The deficiency is that the number of samples selected in this paper is limited, and the selected indicators are also financial indicators. But on the whole, new attempts and explorations have been made in the aspects of index selection and model construction, which has certain research significance and practical value.

\section{Reference}

1. Ludovic Goudenège,Andrea Molent,Antonino Zanette Computing credit valuation adjustment solving coupled PIDEs in the Bates model[J]. Computational Management Science,(prepublish).

2. Stewart Jones,David Johnstone, Roy Wilson.2015. An empirical evaluation of the performance of binary classifiers in the prediction of credit ratings changes[J]. Journal of Banking and Finance, 56.

3. Anonymous.,2009. Office of Advocacy of the U.S. Small Business Administration; Sixteen Percent of High-Impact, High-Tech Firms Founded By Immigrant Entrepreneurs [J]. Politics \& Government Business.

4. Fan bainai, Zhu Wenbin. 2003. Theoretical selection and empirical analysis of credit evaluation index of small and medium-sized enterprises [J]. Scientific research management, (06): 83-88

5. Wang Shuai, Yang peitao, Huang Qingwen (2014) credit risk assessment of small and medium-sized enterprises based on multi-level fuzzy comprehensive evaluation [J]. Financial theory and practice, 35 (05): 13-17 